\title{
Observations on Stabilization Management
}

\author{
A Speech by HOMER JONES, Senior Vice President, \\ Federal Reserve Bank of St. Louis, to the Joint Luncheon, \\ Southern Economic Association and Southern Finance \\ Association, Atlanta, Georgia, November 13, 1970
}

T

HERE IS a prevalent idea that dynamic government action is necessary to effectively restrain prices and promote employment. This has been the prevailing view during the past twenty-five years.

I wish to pose two questions: First, is there evidence that active stabilization management has, on the whole, been desirably effective in the last twentyfive years? Second, does that quarter century of experience suggest that active stabilization management can be desirably effective in the future?

We may list five classes of stabilization tools which are most commonly considered as means of achieving more stable high-level non-inflationary growth, namely, fiscal, monetary, investment funds flow control, changes of economic structure, and price and wage controls. I would like to look at each of these tools in turn.

\section{Fiscal Management}

Let us first look at fiscal management. In undertaking to judge the record of fiscal management, we are faced with a problem of measurement. There are a variety of possible meastres of fiscal action: among these are Federal Government expenditures, high-em. ployment tax receipts, national income accounts tax receipts, high-employment surplus or deficit, and national income accounts surplus or deficit. Scholars are far from agreement as to which of these measures best indicates the influence of fiscal management on total demand, or how they could be amalgamated as a single indicator of fiscal influence. In view of such a confused situation regarding the measurement of fiscal management, it is no wonder that fiscal manage- ment has been less than suecessful in the past twentyfive years.

In any case, no matter how one measures fiscal management, I find no evidence that these magnitudes have followed courses which, in any plausible way, have been related to a desirable course for total spending, for real product, or for prices. In my reading of economic history, I do not find a consistent and predictable relation convincingly demonstrated between any fiscal measure and economic activity. Indeed, I would suggest it is more likely that the fiscal management which we have had has contributed to instability and to limitations on average growth, either directly or indirectly, through its influence on monetary management.

Let me turn to the question of what we now know about whether fiscal management may in the future be able to contribute to stabilization, high employment and growth. That fiscal variations have not on the whole contributed to a successful course of the economy in the past does not necessarily mean that they have not had an effect, or that they could not conceivably have a desirable effect in the future.

Whether fiscal manipulation might be capable of promoting desired economic ends in the future depends on two considerations, the economic and the political. With respect to the economic, we have not been lacking in theories about fiscal influence during the past forty years. Where we stand now about the theories, I shall not attempt to comment. But I shall comment on what research seems to show about a relation of fiscal developments to economic activity. My chief point is that research has not found consistent 
relations, independent of monetary action, between any of the standard measures of fiscal action and simultaneous or subsequent changes in aggregate economic events. The large models which have dealt with this matter have not successfully disentangled the influence of fiscal from the influence of monetary factors. Casual empiricism of observing the course of fiscal management, together with total spending, real production, and prices, does not yield positive conclusions. Our econometric studies at the St. Louis Federal Reserve Bank have not yielded positive relations between high-employment taxes or the high-employment surplus-deficit, when the monetary factors have been held constant. These studies have yielded some positive results with respect to the in " fluence of Federal expenditures, but they are not very impressive.

Some observers may not be impressed with our results. In response, I can only say that we await either suggestions as to how we can make better tests, or the results of the work of others which find, from experience, plausible useful independent relations between fiscal a ctions and crucial economic developments.

But, if we were to find significant and stable relations between fiscal actions and economic developments, could we put them to practical use? Successful application of the knowledge would depend upon useful forecasting of other economic variables which would need to be offset or supplemented. Given the general record, I think we cannot be optimistic about the imminent practicality of such forecasting.

Finally, experience with respect to the political implementation of fiscal management is not impressive. I am not sure that the political problem has made past experience any more adverse than it otherwise would have been; but even if economists did know how to actually manage a budget beneficially, the application might very likely be adverse after political manhandling. It may be that the less it is suggested that the budget is something to be manipulated, the less likely politically we are to get adverse budget results.

\section{Monetury Management}

Let me now turn to our monetary experience. On the whole, it is similar to the fiscal. As in the case of fiscal management ${ }_{z}$ we are plagued by lack of agreement as to proper magnitudes of measurement. But using any of the common measures, examination of the experience of the past twenty-five, fifteen, or ten years, does not indicate that active monetary management has in fact contributed beneficially to stability and optimum levels of employment, prices, and growth. Here again it seems possible that fluctuations in strategic monetary variables may have contributed more to failure to achieve these objectives.

But, even though active monetary management may not in actuality have contributed desirably, experience suggests that monetary developments have had reasonably predictable effects on total spending, real product, employment and prices. Casual empiricism, the research of others which is persuasive to me, and our own econometric studies at St. Louis, have long indicated strong, roughly predictable, relations between monetary action, intentional or unintentional, and the course of the economy. Here, as with our own studies of fiscal management, I realize that many students of these matters may not be fully impressed, if at all. But, here again, we are open to suggestions as to better means of studying past relations between monetary actions and total spending, real product and prices.

Assuming that we have found relations between monetary actions and the course of strategic economic variables, does this mean that we can expect to engage usefully in active monetary management in the future? Here again, we may question whether active monetary manipulation, any more than fiscal, can be expected to eliminate short-run fluctuations as envisaged by the proponents of fine tuning. Because of lags in the effect of monetary actions, we would have to forecast successfully, many months in advance, the course of other factors to be offset or supplemented, and the forecasting record is very poor. And, while I believe that we have positive results regarding monetary effects, we cannot claim that the timing of results is a very exact matter. I therefore conclude that we cannot in the near future engage intelligently in short-run manipulative monetary management.

\section{Oher Stablization Tools}

I now turn briefly to three other social controls which are frequently offered as stabilization tools, though sometimes only as supplements to general fiscal and monetary controls: namely, administrative allocations of the flow of investment funds; structural changes in economic institutions, such as changes in the labor market; and wage and price controls. 
Proposed and actual investment fund allocation management really has nothing to do with stabilization management, but rather with providing a general altemative or supplement to allocation by means of market forces. It is frequently said that tight money squeezes especially and unjustly particular fields of real investment. This matter has entered into rationalizations of Regulation Q management. Actually, adverse effects on certain sectors, such as housing, arise not from tight money policy but from great monetary expansion as in the $1965-68$ period. A steadier monetary expansion, which would probably be desirable on all counts, would remove much of the alleged need for administrative allocation of investment funds. But if there were still a call for allocation different from that provided by the market, this would have nothing to do with stabilization management but with continuous noncyclical economic policy.

With respect to structural changes such as reducing unemployment through improvements in the labor market, these stand on their own merits and have nothing to do with cyclical stabilization policy.

With respect to labor power and corporation power, and their contributions to inflation, I am inclined to say that possible improvements here have little to do with cyclical stabilization. But I suppose there are two ways in which wage-price controls or guidelines may be brought in. First, proponents suggest that wage-price controls are an instrument that should always be available and would come into play in the boom phase of a cycle and then could be held in abeyance at other times. A second, closely related, suggestion is that wage and price controls will be used continually. In this latter instance fiscal and monetary policy would foster a total demand so high that production, employment, and growth would be maximized while demand would not be dissipated in higher prices.

Experience with wage-price guidelines has not been propitious. The guidelines were instituted at a time when we were not having an inflation problem in 1962-64. Then, as they obviously failed in 1965 and 1966, they were quietly dropped. Now, in a time of recession (I do not consider this an evil word, or that it is evil for anything ever to recede, ever so slightly), those who inaugurated the guidelines in recession and abandoned them in inflationary boom propose their reinauguration as a price panacea. It would appear that wage-price controls, rather than being an instrument to be always in effective operation or to be used in boom and laid aside otherwise, are instead to be abandoned during inflationary boom and at all other times to be actively used. On the contrary, I believe, as Paul Samuelson has recently written, "No mixed economy has been able yet to find a satisfactory incomes policy." (New York Times, October 30.)

I personally conclude that experience shows wageprice controls have no semblance of beneficial practicality in any economy which retains any pretence of market determination of the allocation of resources. And we have no evidence that a chronic policy, pressing up inordinately on total spending, will give a higher or steadier employment or production than otherwise, without chronically accelerating inflation. The apparently widespread popular call for administered prices and wages indicates that we have done a poor job teaching economic history and of teaching the role of prices in allocating resources and product.

\section{Historical Background}

It may be useful to try to reconstruct why and how we developed the dogma that active fiscal management was necessary and practical to avoid stagnation at and about a low level of activity. I suggest that out of desperation in the 1930's we had to find something that we could do. The desperate and largely wrong panaceas of the Keynes of 1936 resulted because the prescriptions of the Keynes of thirteen years earlier were ignored.

Possibly we now have again an opportunity to profit from the Keynes of the Tract on Monetary Reform of 1923. Then, Keynes was fighting to achieve monetary management for sound domestic economic stability, freed from the shackles of fixed exchange rates. But Keynes lost, and so occurred one of the great tragedies of modern economic and political history. England retumed to the shibboleth of the fixed exchange rate, and this, in turn, led to the suicidal world monetary policies of 1925-33. Then, in desperation, were created all the elaborate theories that fiscal management could substantially solve the problems of economic instability, and along with this the theory that in the absence of finely-tuned fiscal policy an economy might most likely stabilize at or fluctuate far below optimum employment and production.

Now we should put ourselves back with the Keynes of 1923. We should abandon the chimerat that it is either necessary or practical to actively manage a fiscal policy in the interest of stable high-level economic activity. Our experience indicates that, even as in 1923 , the main key to a satisfactory operation of 
the economic system is not to permit a fixed exchange rate system to dictate disastrous monetary contrac. tion, as in 1925 33 . The other side of the coin is that, given this freedom, we should equally avoid inordinate monetary expansion.

It may be instructive to consider how much happier we might have been in the last forty years if Keynes had been successful in 1923-25 - if Britain had not hung about her neck the albatross of a $\$ 4.87$ pound, and the other leading nations of the world had not subsequently been preoccupied with defending their currencies. We would have had a good chance of avoiding $1929-33$ and all the troubles which that period brought in train economically, politically, and militarily.

If we have had reasonably good economic performance during the past twenty-five years in this country, and in most other countries, we cannot ascribe it to the success of active manipulation of fiscal and monetary management. Rather, it is due to the inherent strength of what are still, on the whole, free market economies. It has depended upon avoiding, on the whole, shocking monetary and fiscal mismanagement such as in England in 1925, and in the United States in 1929-33 and 1936-37.

Having said so many negative things, let me make a few positive remarks. In the field of fiscal management we should avoid gyrations of the highemployment surplus or deficit. For purposes of promoting national saving, investment and growth, I would prefer a substantial high-employment surplus. But this is less crucial than budget stability. Similarly, in the monetary field, the most important objective for policy is to avoid gyrations. Until we can get better information upon which to base our actions, I believe a steady growth of money gives a better chance of getting a steady growth of total spending, real product and employment, and a tolerable price trend than does any other procedure. In such a fiscal and monetary setting, the market economy has a better chance of following the high stable growth trend which we desire than does any altemative procedure apparent to us at present. But this is not easy. We know from experience that avoiding unintended gyrations in strategic fiscal and monetary variables requires eternal vigilance.

\section{Conclustons}

In conclusion, I have two points, one concerning what economists should be teaching, and the other dealing with the problem of current policy.
Economists have spent a generation teaching that there are some magic tools of fiscal policy, and more recently of monetary policy, which, if managed according to some scientific principles, supposed to be well known to the experts, can be used and must be used incessantly and with finesse to give us satisfactory operation of the economy. Will the profession now have enough fortitude to face and teach the facts? We should now, while saving as much face as possible, tell the public that we do not know how to finely manage the econony, and that, the way the fiscal and monetary tools have been used in the last twenty-five years, manipulation has probably done more harm than good. We should inform the public that the best we can do - and it will be a major improvement - is, on the one hand, to avoid mistakes such as the monetary and fiscal excesses of 1965-68 and, on the other hand, to avoid letting monetary expansion be led around by fixed exchange rates and by money market conditions.

Finally, where are we just now and what course shall we follow? Despite my negative remarks about active, positive fiscal and monetary management, bad management can give us massive trend disturbances, as did the monetary collapse of 1929-33, the war inflations, and the inflation of 1965-69.

Such massive disturbances, which could and should have been avoided, not only have their immediate social evils, but they create the problem of what, if anything, fiscal or monetary management can do to restore stability. It is this last problem we have now been struggling with for the past two years.

Let me emphasize that our present not too happy situation derives from gross fiscal and monetary mismanagement in 1965-68, when with shocking suddenness, we accelerated Federal expenditures, turned a high-employment surplus into a great deficit, and accelerated monetary expansion. Having made these grave errors, which brought inflation and expectations of inflation, what to do has been a great problem.

It is sometimes said that we are experiencing the worst of all possible worlds - we continue to have inflation and real product is not growing. But I believe that this situation is the inevitable result of the best possible choice among the three alternatives which were available to us. First, we could have fostered a total spending which would have temporarily better maintained production and employment, but which would have provided accelerating inflation. 
Second, we could have achieved a faster reduction of inflation, but that would have involved less real product and more unemployment than we have achieved. Third, we could choose a course between these alternatives, and this we have done.

The course we chose has meant, is meaning, and, if pursued, will continue to mean, only slowly declining inflation, retarded growth of real product, and rising unemployment. If we had not made the gross errors of 1965-68, we would not subsequently have had the painful choice between accelerating inflation and the restricted production and employment which we are now experiencing.

Given our decisions and our present situation, we can now expect that, if we avoid erratic fiscal and monetary action, real product and employment growth will accelerate gradually over the next few years, and the upward trend of prices will end or become nominal. In time we can obviate the results of the 1965-68 mistakes and can achieve a practical optimum of employment, real growth and price trends.

In my judgment, given the errors of 1965-68, subsequent developments have been as good as could be expected. One trouble has been that the economics profession has led the public to believe that there could be miraculous correction of the price trends without pain. That was not possible in 1969-70 and it is not now possible in the immediate future.

We should not pretend to the public that there is some "game plan" which will magically and painlessly avoid the results of the errors of 1965-68 along some time-path of short duration. It is sometimes said that the fiscal and monetary actions since June 1968 or since January 1969 have grossly failed. I do not think they have failed. They have done what was in the nature of the economic universe that they could accomplish. And I cannot see, on a basis of hindsight, that we could have made another choice that would have given us a better pattem of results.

\section{MONEY SUPPLY REVISED}

ATA FOR currency held by the public, demand deposits held by the public, and time deposits at all commercial banks have been revised by the Federal Reserve Board. The revision includes a minor adjustment for seasonal factors and for new benchmark data on nonmember bank deposits. In addition, a major revision of the demand deposit component of money was made in order to eliminate a measurement error created by a rising and volatile volume of transactions carried out by certain specialized international banking institutions. ${ }^{1}$

The underestimation arose from including items arising from transactions made by international banking institutions in "cash items in the process of collection" while being cleared between U.S. banks, and also from including the deposits of these international banking institutions in interbank deposits by U.S. banks. Since both "cash items" and interbank deposits are subtracted from gross demand deposits in computing the measured money stock, double subtracting resulted. The underestimation was corrected by adding to gross demand deposits the liabilities of international banking institutions which correspond to "cash items" on the books of U.S commercial banks.

The revision raised the level and the rates of change of the money stock. For example, money averaged $\$ 206$ billion in October for the old series, compared with $\$ 213$ billion for the new series. The 5.5 per cent rate of change in money from December 1969 to November 1970 compares with a 3.8 per cent rate using the old series." In the previous eleven months from January 1969 to December 1969 , money grew at a 3 per cent rate according to the new series and at about a 2 per cent rate according to the old series.

\footnotetext{
1These institutions are agencies and branches of foreign banks and subsidiaries of U.S. Banks organized under the Edge Act to engage in international banking.

2 November estimated for the old series.
} 